\title{
Article \\ Clinical and Laboratory Features of JAK2 V617F, CALR, and MPL Mutations in Malaysian Patients with Classical Myeloproliferative Neoplasm (MPN)
}

\author{
Razan Hayati Zulkeflee ${ }^{1,2}\left(\mathbb{D}\right.$, Zefarina Zulkafli ${ }^{1,2, *} \mathbb{C}$, Muhammad Farid Johan ${ }^{1}\left(\mathbb{D}\right.$, Azlan Husin ${ }^{2,3}$, \\ Md Asiful Islam ${ }^{1}$ D and Rosline Hassan ${ }^{1,2, *}$ \\ 1 Department of Haematology, School of Medical Sciences, Universiti Sains Malaysia, \\ Kubang Kerian 16150, Malaysia; rhayatiz@usm.my (R.H.Z.); faridjohan@usm.my (M.F.J.); \\ asiful@usm.my (M.A.I.) \\ 2 Hospital Universiti Sains Malaysia, Kubang Kerian 16150, Malaysia; azlanh@usm.my \\ 3 Department of Internal Medicine, School of Medical Sciences, Universiti Sains Malaysia, \\ Kubang Kerian 16150, Malaysia \\ * Correspondence: zefarinazulkafli@gmail.com (Z.Z.); roslin@usm.my (R.H.)
}

check for updates

Citation: Zulkeflee, R.H.; Zulkafli, Z.; Johan, M.F.; Husin, A.; Islam, M.A.; Hassan, R. Clinical and Laboratory Features of JAK2 V617F, CALR, and MPL Mutations in Malaysian Patients with Classical Myeloproliferative Neoplasm (MPN). Int. J. Environ. Res. Public Health 2021, 18, 7582. https:// doi.org/10.3390/ijerph18147582

Academic Editor: Atsushi Nonami

Received: 27 May 2021

Accepted: 14 July 2021

Published: 16 July 2021

Publisher's Note: MDPI stays neutral with regard to jurisdictional claims in published maps and institutional affiliations.

Copyright: (c) 2021 by the authors. Licensee MDPI, Basel, Switzerland. This article is an open access article distributed under the terms and conditions of the Creative Commons Attribution (CC BY) license (https:/ / creativecommons.org/licenses/by/ $4.0 /)$.

\begin{abstract}
Mutations of JAK2V617F, CALR, and MPL genes confirm the diagnosis of myeloproliferative neoplasm (MPN). This study aims to determine the genetic profile of JAK2V617F, CALR exon 9 Type 1 (52 bp deletion) and Type 2 (5 bp insertion), and MPL W515 L/K genes among Malaysian patients and correlate these mutations with clinical and hematologic parameters in MPN. Mutations of JAK2V617F, CALR, and MPL were analyzed in 159 Malaysian patients using allele-specific polymerase chain reaction, including 76 polycythemia vera (PV), 41 essential thrombocythemia (ET), and 42 primary myelofibrosis (PMF) mutations, and the demographics of the patients were retrieved. The result showed that $73.6 \%$ JAK2V617F, 5.66\% CALR, and $27.7 \%$ were triple-negative mutations. No MPL W515L/K mutation was detected. In ET and PMF, the predominance type was the CALR Type 1 mutation. In JAK2V617F mutant patients, serum LDH was significantly higher in PMF compared to PV and ET. PV has a higher risk of evolving to post PV myelofibrosis compared to ET. A thrombotic event at initial diagnosis of $40.9 \%$ was high compared to global incidence. Only one PMF patient had a CALR mutation that transformed to acute myeloid leukemia. JAK2V617F and CALR mutations play an important role in diagnostics. Hence, every patient suspected of having a myeloproliferative neoplasm should be screened for these mutations.
\end{abstract}

Keywords: hematologic malignancies; chronic myeloproliferative neoplasm; molecular biology; polycythemia vera; essential thrombocythemia; primary myelofibrosis; JAK2V617F; calreticulin; MPL

\section{Introduction}

Myeloproliferative neoplasms (MPNs) are clonal hematopoietic disorders that harbor somatic mutations characterized by the excessive production of one or more terminally differentiated myeloid lineages. MPN is classified into (i) chronic myeloid leukemia (BCRABL1-positive), (ii) polycythemia vera (PV), (iii) essential thrombocythemia (ET), (iv) primary myelofibrosis (PMF), (v) chronic neutrophilic leukemia, (vi) chronic eosinophilic leukemia-not otherwise specified (NOS), and (vii) MPN-unclassifiable. Although most of the MPNs are indolent, MPNs have the potential to become thromboembolic and/or bleeding events and can transform into acute leukemia or myelofibrosis [1-3].

Mutations of $J A K 2-V 617 F, C A L R$, and MPL account for over $90 \%$ of MPN cases and are usually mutually exclusive to diagnosis. However, around $10 \%$ of those MPN driver mutations are still unknown, and these patients are defined as triple-negative MPN (TNMPNs) [4]. The diagnostic driver gene mutation hallmark in MPN, especially in PV, is JAK2-V617F [5], while the second common mutation, mainly in ET and PMF, is the CALR 
mutation detected in $25 \%$ of MPN patients. The MPL mutation has been reported in 4-6\% of ET and PMF individuals [6].

The Janus kinase 2 (JAK2) gene is mapped to chromosome 9p24.1 in humans [7]. In normal hematopoietic cells, JAK2 is characterized by the presence of two homologous kinases: one is an enzymatically active kinase domain (JAK homology 1 ; JH1) and the other comprises a catalytically inactive pseudokinase domain (JH2) that inhibits the kinase activity of JAK2 following ligand binding [8]. The most common mutation involves the substitution of valine with phenylalanine at position 617 in the JH2 domain (JAK2-V617F) located in exon 14, resulting in disrupts of normal inhibitory function towards the JH1 kinase domain. This mutation also induces excessive myeloid progenitor cell proliferation and activity by directly activating the JH1 domain through the SH2-JH2 link [9].

The calreticulin $(C A L R)$ chaperone protein-encoding gene is mapped on chromosome 19 p13 in humans and contains nine exons. The CALR is a multifunctional protein that resides mainly in the endoplasmic reticulum and cytoplasm. It has several functions that contribute to calcium homeostasis, and it acts as a chaperone in interactions with MPL and JAK/STAT signaling, controlling cell proliferation and survival [10]. The most common mutations involved at either 52 base pair deletions (referred to as Type 1) or 5 base pair insertions (Type 2) are restricted to exon 9, which generates a +1 base-pair frameshift, eliminating most of the $\mathrm{C}$-terminal domain and disrupting the $\mathrm{Ca}++$ binding process [11].

The myeloproliferative leukemia (MPL) gene, mapped to chromosome 1p34, has 12 exons residing at the juxtamembrane region of the thrombopoietin receptor protein (TPOR). MPL is a regulator of thrombopoietin (TPO) levels; it is a negative feedback mechanism that eliminates TPO bound to the MPL receptor. MPL and TPO are two essential proteins for hematopoietic stem cell self-renewal and DNA repair [12]. The binding of TPO to the MPL receptor initiates signaling through JAK2. Several mutations of MPL have been identified. W515L (tryptophan-to-leucine substitution) and W515K (tryptophan-to-lysine substitution) are the most commonly involved mutations that occur within exon 10; they lead to the loss of auto-inhibition of the thrombopoietin receptor, which results in continuous activation.

Laboratory diagnosis of MPN is made based on peripheral blood count, bone marrow trephine biopsy morphology, biochemical investigations, BCR-ABL, and/or a positive finding for at least driver gene mutations or clonal proliferation (updated WHO 2016 criteria) $[13,14]$. Figure 1 shows the bone marrow trephine morphological features based on the updated WHO 2016 criteria for PV, ET, and PMF, respectively.

It is important to perform genetic testing to confirm the diagnosis of MPNs. To date, genetic testing is not done in many parts of the world to confirm MPNs. Therefore, this study aims to determine the genetic profile of JAK2 V617F, CALR exon 9 Type 1 (52 bp deletion) and Type 2 ( 5 bp insertion), and MPL W515 L/K genes among Malaysian patients using allele-specific polymerase chain reaction and to correlate these mutations with clinical and laboratory parameters. 

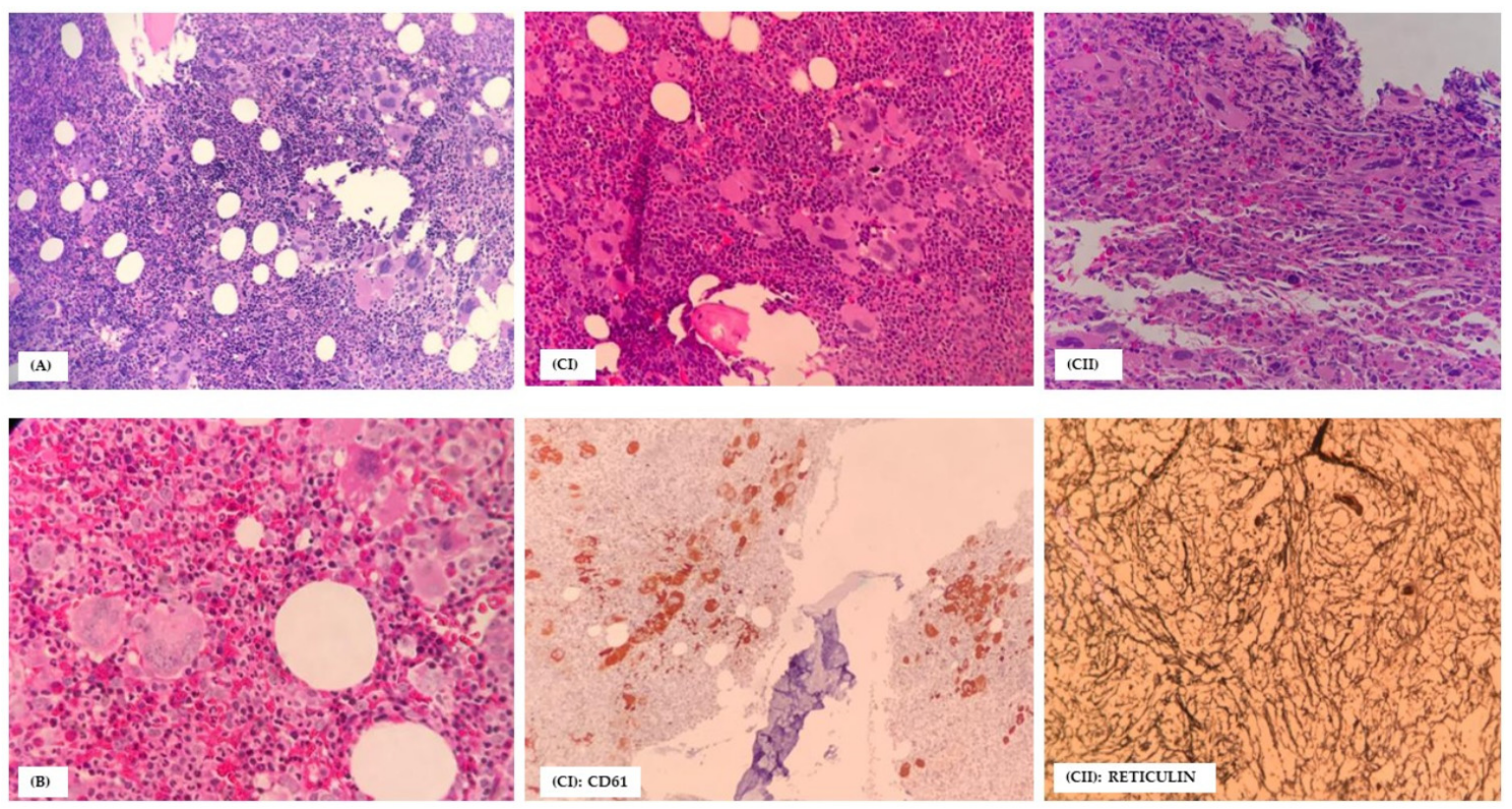

Figure 1. H\& E (A) Polycythemia vera; hypercellularity with panmyelosis(especially erythroid precursors and prominent megakaryocytes). The florid megakaryocytes admixture of small, normal to large pleomorphic morphology and arranged in loose clusters. Dilated sinus containing red blood cells. (B) Essential thrombocythemia; normal in cellularity, proliferation of abnormally giant or large form of atypical megakaryocytes, abundant cytoplasm, scattered throughout the marrow spaces. Erythropoiesis and granulopoiesis were within normal. (C) Primary myelofibrosis; (CI) pre-PMF: hypercellularity with a proliferation of atypical megakaryocytic arranged in dense or large clusters and usually adjacent to vascular sinus and bony trabeculae. Megakaryocytes morphology (high nuclear-cytoplasmic ratio, abnormal chromatin clumping, (CII) Overt PMF: Variable cellularity with (sometimes) absence of hematopoietic cells, dense reticulin, atypical megakaryocytes, usually in sheets and within the dilated sinuses.

\section{Materials and Methods}

This was a cross-sectional and cohort study over five years. This study was approved by the Universiti Sains Malaysia Research Ethics Committee (USM/JEPeM 19100646) and carried out in accordance with the Declaration of Helsinki. In this study, 159 patient records were obtained from the Hematology Laboratory of Hospital Universiti Sains Malaysia (Hospital USM). The following inclusion selection criteria were applied: (1) 20 years old and above at the time of diagnosis and (2) diagnosis of MPN, as strictly defined by the criteria of the 2016 WHO classification guidelines. The diagnostic DNA samples were retrieved from the laboratory from 2016 until 2020. The clinical and laboratory data obtained were age, gender, white blood cell (WBC) and differential counts, hemoglobin $(\mathrm{Hb})$, platelet (plt), hematocrit $(\mathrm{HCT})$, lactate dehydrogenase $(\mathrm{LDH})$, spleen and liver size, thrombotic and hemorrhagic event, progression of disease, and JAK2V617F mutation status. Mutational analyses (CALR and $M P L$ ) were performed using archived extracted genomic DNA and newly diagnosed samples. Isolation of genomic DNA from newly collected peripheral blood was carried out using QIAamp DNA Blood Mini Kits (QIA Symphony SP, Qiagen Company, Hilden, Germany), adhering to the protocol described by the manufacturer [15]. JAK2V617F, CALR, and MPL mutational status were determined via allele-specific oligonucleotide primers polymerase chain reaction (PCR) with to the $5^{\prime}$ and $3^{\prime}$ ends of exon 14 of $J A K 2$, exon 9 of $C A L R$, and exon 10 of $M P L$, respectively, which were done through the NCBI nucleotide BLAST program (https:/ /blast.ncbi.nlm. nih.gov/Blast.cgi; accessed on 8 July 2019). The following accession numbers of DNA, primers, PCR reaction, and PCR reaction volume were used for PCR amplification of the JAK2V617F, CALR, and MPL mutations (Appendix A). The PCR reaction mixture was up in the total volumes of $25 \mu \mathrm{L}$ from constituents, and the reactions were placed in a Veriti PCR thermal cycler following the PCR profile from the reference stated. The PCR products 
were electrophoresed on $1.5 \%$ agarose gel for $30 \mathrm{~min}$ (Figure 2). Both CALR and MPL gene mutations were confirmed by Sanger sequencing [16].
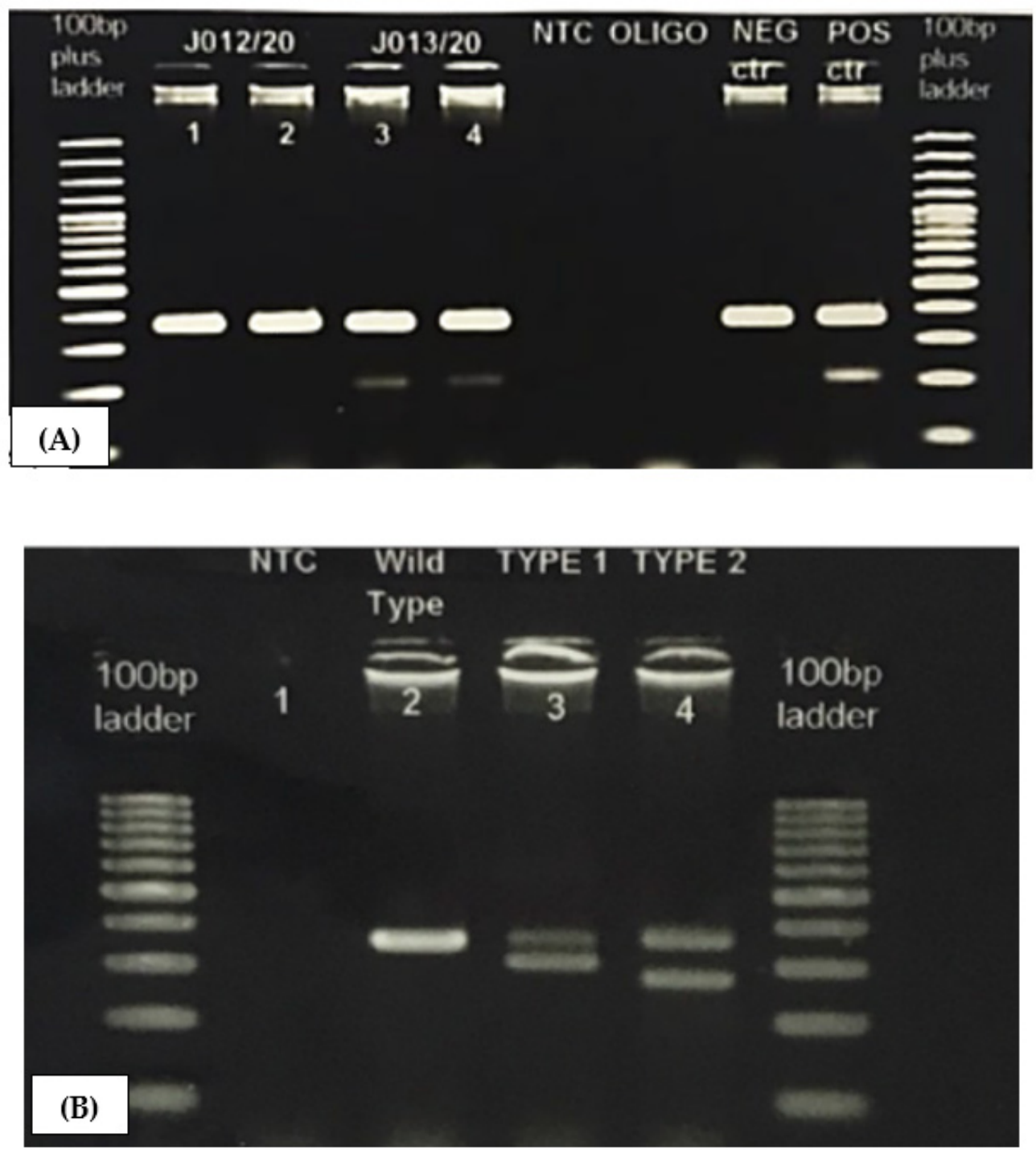

Figure 2. PCR products with gel electrophoresis. Electrophoresis of amplified PCR products to detect (A) JAK2 V617F mutations: Lanes 1-2 are normal cases with only wild-type at 364 bp, Lanes 3-4 are positive for the JAK2 V617F mutation, with wild-type at $364 \mathrm{bp}$ and a mutant band at $203 \mathrm{bp}$; (B) CALR mutations: Lane 2 is a normal case with only wild-type at $357 \mathrm{bp}$, Lane 3 is positive for CALR Type 1 (302 bp), and Lane 4 is positive for CALR Type 2 (272 bp).

The results were analyzed by Statistical Package for the Social Sciences (SPSS) Statistics for Windows (Version 25.0; IBM Corp., Armonk, NY, USA). For parametric data, comparisons between patient characteristics were performed by the chi-square method for categorical variables and the independent $t$-test for the numerical data. Additionally, the Mann-Whitney U-test and Fisher's exact test were used for nonparametric and qualitative variables, respectively. $p$-values less than 0.05 were considered to indicate statistically significant data.

\section{Results}

The clinical and laboratory features of patients with chronic MPN are summarized in Table 1. A total of 159 patients were studied; $89(56 \%)$ were male and $70(44 \%)$ were female, with mean and standard deviation ages of 57.18 (13.52) years. Of the 159 patients, MPN 
was classified into 76 (47.8\%) PV, 41 (25.8\%) ET, and 42 (26.4\%) PMF. Mean hemoglobin, leukocyte and differential counts, platelet counts, and LDH are shown in Table 1. One PMF patient transformed to acute myeloid leukemia after more than 10 years from diagnosis, and $5(3.1 \%)$ PV patients progressed to myelofibrosis.

Table 1. Clinical and laboratory features of patients $(n=159)$ with chronic MPN.

\begin{tabular}{|c|c|c|c|c|}
\hline \multirow[b]{2}{*}{ Characteristic } & \multirow[b]{2}{*}{ MPN $(n=159)$} & \multicolumn{3}{|c|}{ Disease Subtype } \\
\hline & & $\mathrm{PV}(n=76)$ & $\mathrm{ET}(n=41)$ & PMF $(n=42)$ \\
\hline $\operatorname{Sex}(\mathrm{M} / \mathrm{F})$ & $89 / 70$ & $49 / 27$ & $19 / 22$ & $21 / 21$ \\
\hline \multicolumn{5}{|c|}{ Mean (SD) } \\
\hline Age at diagnosis & $57.18(13.52)$ & $58.66(13.90)$ & $53.98(14.43)$ & $57.66(11.49)$ \\
\hline $\mathrm{Hb}(\mathrm{g} / \mathrm{dL})$ (Range) & $14.85(3.79)$ & $\begin{array}{c}17.26(2.97) \\
(7.7-23.4)\end{array}$ & $\begin{array}{c}13.54(2.1) \\
(9-18)\end{array}$ & $\begin{array}{c}11.68(3.12) \\
(6.5-20.2)\end{array}$ \\
\hline Hct $(\%)$ & $46.95(12.55)$ & $54.78(10.14)$ & $41.74(7.35)$ & $37.65(10.67)$ \\
\hline WBC $\left(\times 10^{9} / \mathrm{L}\right)($ Range $)$ & $17.15(14.02)$ & $\begin{array}{c}17.22(10) \\
(4.02-55.57)\end{array}$ & $\begin{array}{c}15.02(14.58) \\
(7.18-97.7)\end{array}$ & $\begin{array}{c}17.16(16.77) \\
(2.7-76.4)\end{array}$ \\
\hline Platelets $\left(\times 10^{9} / \mathrm{L}\right)$ (Range) & $645.82(399.76)$ & $\begin{array}{c}599.36(375.4) \\
(94-1752)\end{array}$ & $\begin{array}{c}901.29(289.29) \\
(305-1597)\end{array}$ & $\begin{array}{l}534.39(446.3) \\
(22-2035)\end{array}$ \\
\hline Monocyte $\left(\times 10^{9} / \mathrm{L}\right)$ & $1.02(1.44)$ & $0.78(0.32)$ & $0.65(0.34)$ & $1.25(1.51)$ \\
\hline Basophil $\left(\times 10^{9} / \mathrm{L}\right)$ & $0.23(0.55)$ & $0.24(0.64)$ & $0.10(0.08)$ & $0.31(0.55)$ \\
\hline Eosinophil $\left(\times 10^{9} / \mathrm{L}\right)$ & $0.61(1.69)$ & $0.50(0.52)$ & $0.34(0.26)$ & $0.58(1.54)$ \\
\hline $\begin{array}{l}\mathrm{LDH}(\mathrm{U} / \mathrm{L}) \\
\mathrm{ULN}>400\end{array}$ & $867.45(827.08)$ & $704.63(406.24)$ & $624.07(336.75)$ & $1141.7(1331.01)$ \\
\hline Hepatomegaly * & $44(27.7)$ & $17(22.4)$ & $7(17.0)$ & $20(47.6)$ \\
\hline Splenomegaly * & $69(43.4)$ & $28(36.8)$ & $15(36.6)$ & $26(61.9)$ \\
\hline Thrombosis * & $65(40.9)$ & $32(42.1)$ & $15(36.6)$ & $18(42.9)$ \\
\hline Hemorrhage * & $2(1.26)$ & $1(1.31)$ & $1(2.43)$ & 0 \\
\hline Transformed * & $6(3.77)$ & $5(6.57)$ & & $1(2.38)$ \\
\hline
\end{tabular}

*All of these variables are presented as $n(\%)$.

Of the 76 patients diagnosed with PV, 49 (64.5\%) were male and 27 (35.5\%) were female, with a mean age of 58.66 (13.90) years (range, 20-80 years). Splenomegaly was present in $36.8 \%$ of patients. The second type of MPN was primary myelofibrosis, with 42 patients recruited. The mean age was 57.66 (11.49) years (range, 32 to 79). Splenomegaly was present in $61.9 \%$ of patients. Forty-one patients were diagnosed with ET; $46 \%$ were male and 54\% were female. The mean age was 53.98 (14.43) years (range, 23-86 years). Splenomegaly was present in $36.6 \%$ of patients. Thrombosis at the time of diagnosis was a frequent manifestation, with an overall prevalence of $40.9 \%$.

Table 2 shows the prevalence of three driver gene mutations in different types of MPN. A total of 117 (73.6\%) MPN patients were detected with the JAK2V617F mutation. The detection rates of the JAK2V617F mutation in PV, ET, and PMF patients were $86.8 \%$ $(66 / 76), 70.7 \%(29 / 41)$, and 52.3\% (22/42), respectively. Nine cases (5.66\%) of CALR gene exon 9 mutations were detected, which were found to be mutually exclusive in ET and PMF patients. Based on the MPN subtypes, CALR gene mutations were detected in $7.31 \%$ of ET patients, and all were Type 1. In contrast, in PMF, the CALR gene mutation was found in $14.3 \%$ of patients; $66.7 \%$ and $33.3 \%$ were Type 1 and Type 2 , respectively. No MPL W515L/K mutations were detected in all types of MPN. Additionally, 27.7\% of MPN patients were triple-negative. No coexistence of two or more gene mutations was detected.

Table 2. Prevalence of $J A K 2^{V 617 F}, C A L R$, and MPL gene mutations.

\begin{tabular}{cccc}
\hline Characteristic & ET $[n=41(\%)]$ & PMF $[n=42(\%)]$ & PV $[n=76(\%)]$ \\
\hline$J A K 2 V 617 F$ & $29(70.7)$ & $22(52.3)$ & $66(86.8)$ \\
CALR exon 9+ & $3(7.3)$ & $6(14.3)$ & 0 \\
MPL exon 10+ & 0 & 0 & 0 \\
Triple negative & $9(21.9)$ & $14(33.4)$ & - \\
\hline
\end{tabular}


Table 3 demonstrates the breakdown of MPN subtypes according to JAK2V617F mutation status. The group of PV JAK2V617F-positive patients presented at an older age $(p<0.05)$, with significantly high platelet counts and high leukocyte counts $(p<0.001)$; $24.2 \%$ and $37.9 \%$ of patients with PV with the JAK2V617F mutation had hepatomegaly and splenomegaly, respectively. ET patients with the JAK2V617F mutation had higher hemoglobin levels $(p<0.005)$ and increased leukocyte and granulocyte counts. No patient progressed to the blast phase or was transformed to the fibrosis stage.

$J A K 2 V 617 F$ mutation-positive patients were also analyzed within different subtypes of MPN patients (Table 3). It is as expected that hemoglobin and platelet counts were significantly higher in PV $(p<0.05)$ and ET $(p=0.001)$, respectively, compared with other subtypes. Serum LDH was significantly higher in PMF $(p=0.008)$ compared to PV and ET.

Table 4 summarizes the clinical and laboratory features of ET and PMF patients, stratified according to the JAK2V617F, CALR mutation and triple-negative status. Univariate analysis was performed on patients with ET. It was noted that those with CALR mutations were associated with higher platelet counts, higher LDH levels, and lower thrombotic events. For PMF, the univariate analysis in patients with the CALR mutation showed very high serum LDH and increased platelet counts, but they were protected from thrombosis. None had any thrombotic events to date. One patient with CALR mutations had leukemic transformation to acute myeloid leukemia. 
Table 3. Clinicohematological parameters of $J A K 2^{V 617 F}$ positive and negative cases according to MPN subtypes.

\begin{tabular}{|c|c|c|c|c|c|c|c|c|c|c|c|c|}
\hline \multirow[b]{2}{*}{ Parameter } & \multicolumn{3}{|c|}{$\begin{array}{c}\text { PV } \\
\text { Mean (SD) } / n(\%)\end{array}$} & \multicolumn{3}{|c|}{$\begin{array}{c}\text { ET } \\
\text { Mean (SD)/n (\%) }\end{array}$} & \multicolumn{3}{|c|}{$\begin{array}{c}\text { PMF } \\
\text { Mean (SD) } / n(\%)\end{array}$} & \multirow[b]{2}{*}{$\begin{array}{l}p \text {-Value } \\
(a \text { vs. b) }\end{array}$} & \multirow[b]{2}{*}{$\begin{array}{l}p \text {-Value } \\
(\text { b vs. c) }\end{array}$} & \multirow[b]{2}{*}{$\begin{array}{l}p \text {-Value } \\
(a \text { vs. })\end{array}$} \\
\hline & $\begin{array}{l}\text { JAK2V617F } \\
\text { Positive } \\
n=66 \\
\text { (a) }\end{array}$ & $\begin{array}{l}J A K 2 V 617 F \\
\text { Negative } \\
n=10\end{array}$ & p-Value & $\begin{array}{l}\text { JAK2V617F } \\
\text { Positive } \\
n=29 \\
\text { (b) }\end{array}$ & $\begin{array}{l}J A K 2 V 617 F \\
\text { Negative } \\
n=12\end{array}$ & p-Value & $\begin{array}{l}\text { JAK2V617F } \\
\text { Positive } \\
n=22 \\
\text { (c) }\end{array}$ & $\begin{array}{l}J A K 2 V 617 F \\
\text { Negative } \\
n=20\end{array}$ & $p$-Value & & & \\
\hline + Gender, Male * & $40(60.6)$ & $9(90)$ & 0.087 & $12(41.3)$ & $7(58.3)$ & 0.322 & $8(36.4)$ & $13(65)$ & 0.064 & 0.117 & 0.778 & 0.778 \\
\hline$\ddagger$ Age, years & $60.36(13.49)$ & $\begin{array}{l}47.40 \\
(11.62)\end{array}$ & 0.005 & $\begin{array}{l}54.79 \\
(12.77)\end{array}$ & $52(18.32)$ & 0.579 & $\begin{array}{l}60.05 \\
(10.59)\end{array}$ & $\begin{array}{l}55.45 \\
(12.09)\end{array}$ & 0.20 & 0.988 & 0.346 & 0.346 \\
\hline$\ddagger \mathrm{Hb}(\mathrm{g} / \mathrm{dL})$ & $17.2(3.15)$ & $17.7(1.25)$ & 0.368 & $14.1(2.0)$ & $12.2(1.75)$ & 0.007 & $11.73(3.7)$ & $11.54(2.4)$ & 0.847 & 0.028 & 0.003 & 0.003 \\
\hline$\ddagger \mathrm{HCT}(\%)$ & $55.06(10.78)$ & $52.93(3.62)$ & 0.231 & $43.53(7.37)$ & $37.43(5.42)$ & 0.14 & $\begin{array}{l}36.64 \\
(10.79)\end{array}$ & $\begin{array}{l}38.37 \\
(10.74)\end{array}$ & 0.607 & 0.033 & 0.054 & 0.054 \\
\hline$\ddagger \mathrm{WBC}\left(\times 10^{9} / \mathrm{L}\right)$ & $18.5(10.01)$ & $8.82(3.76)$ & $<0.001$ & $16.71(17.1)$ & $10.93(1.75)$ & 0.253 & $\begin{array}{l}20.86 \\
(16.04)\end{array}$ & $\begin{array}{l}16.61 \\
(17.69)\end{array}$ & 0.42 & 0.02 & 0.672 & 0.672 \\
\hline $\begin{array}{l}\ddagger \text { Platelets } \\
\left(\times 10^{9} / \mathrm{L}\right)\end{array}$ & $\begin{array}{l}653.56 \\
(373.15)\end{array}$ & $\begin{array}{l}241.6 \\
(70.51)\end{array}$ & $<0.001$ & $\begin{array}{l}875.31 \\
(290.3)\end{array}$ & $\begin{array}{l}964.1 \\
(289.34)\end{array}$ & 0.378 & $\begin{array}{l}698.64 \\
(467.57)\end{array}$ & $\begin{array}{l}426.2 \\
(383.76)\end{array}$ & 0.47 & 0.001 & 0.092 & 0.092 \\
\hline $\begin{array}{l}\ddagger \text { Monocyte } \\
\left(\times 10^{9} / \mathrm{L}\right)\end{array}$ & $0.78(0.34)$ & $0.76(0.17)$ & 0.790 & $0.69(0.37)$ & $0.57(0.27)$ & 0.383 & $1.37(1.13)$ & $1.42(1.89)$ & 0.927 & 0.279 & 0.047 & 0.002 \\
\hline $\begin{array}{l}\ddagger \text { Basophil } \\
(\times 109 / \mathrm{L})\end{array}$ & $0.27(0.70)$ & $0.05(0.02)$ & 0.347 & $0.11(0.08)$ & $0.07(0.05)$ & 0.154 & $0.41(0.62)$ & $0.2(0.44)$ & 0.256 & 0.07 & 0.054 & 0.448 \\
\hline $\begin{array}{l}\ddagger \text { Eosinophil } \\
(\times 109 / \mathrm{L})\end{array}$ & $0.54(0.56)$ & $0.28(0.22)$ & 0.172 & $0.35(0.21)$ & $0.34(0.36)$ & 0.974 & $1.01(2.03)$ & $0.17(0.17)$ & 0.087 & 0.398 & 0.217 & 0.158 \\
\hline $\begin{array}{l}\ddagger \mathrm{LDH}(\mathrm{U} / \mathrm{L}) \\
\mathrm{ULN}>400\end{array}$ & $\begin{array}{l}763.81 \\
(370.73)\end{array}$ & $670(551.52)$ & 0.516 & $\begin{array}{l}602.6 \\
(267.3)\end{array}$ & $66.8(450.2)$ & 0.659 & $\begin{array}{l}1162.37 \\
(1087.03)\end{array}$ & $\begin{array}{l}1350.19 \\
(1605.37)\end{array}$ & 0.684 & 0.058 & 0.008 & 0.008 \\
\hline $\begin{array}{l}\text { † Hepatomegaly } \\
*\end{array}$ & $16(24.2)$ & $1(10)$ & 0.441 & $3(10.3)$ & $4(33.3)$ & 0.165 & $13(59.1)$ & $7(35)$ & 0.118 & 0.119 & 0.002 & $<0.001$ \\
\hline $\begin{array}{l}\text { † Splenomegaly * } \\
\text { † Thrombotic }\end{array}$ & $25(37.9)$ & $3(30)$ & 0.737 & $10(34.5)$ & $5(41.7)$ & 0.73 & $17(77.2)$ & $9(45)$ & 0.31 & 0.752 & 0.484 & 0.002 \\
\hline events, ${ }^{*}$ & $26(39.4)$ & $6(60)$ & & $12(41.3)$ & $3(25)$ & & 7 (31.8) & $11(55)$ & & & & \\
\hline - $\quad$ Artery & $21(80.8)$ & $6(100)$ & 0.306 & $11(91.7)$ & $1(33.3)$ & 0.48 & $5(71.4)$ & $1(9.1)$ & 0.129 & 0.856 & $<0.001$ & 0.484 \\
\hline - Vein & $5(19.2)$ & 0 & & $1(8.3)$ & $2(66.7)$ & & $2(28.6)$ & $10(90.9)$ & & & & \\
\hline † Transformed * & $5(7.5)$ & 0 & 1 & 0 & 0 & - & 0 & 1 (Type 1 ) & 0.488 & - & - & - \\
\hline
\end{tabular}


Table 4. Clinical and laboratory features of 41 Malaysian patients with PMF and 42 patients with ET, stratified according to mutation profiles.

\begin{tabular}{|c|c|c|c|c|c|c|c|c|c|c|c|c|}
\hline \multirow[b]{2}{*}{$\begin{array}{c}\text { Variables } n(\%) \\
\text { Median (Range) }\end{array}$} & \multicolumn{6}{|c|}{ PMF $; n=42$} & \multicolumn{6}{|c|}{$\mathrm{ET} ; n=41$} \\
\hline & $\begin{array}{l}J A K 2 V 617 F \\
\text { Mutation } \\
n=22 \\
\text { (a) }\end{array}$ & $\begin{array}{c}\text { CALR } \\
\text { Mutation } \\
n=6 \\
\text { (b) }\end{array}$ & $\begin{array}{l}\text { Triple } \\
\text { Negative } \\
n=14 \\
\text { (c) }\end{array}$ & $\begin{array}{l}p \text {-Value } \\
\text { (a vs. b) }\end{array}$ & $\begin{array}{l}p \text {-Value } \\
(\text { b vs. c) }\end{array}$ & $\begin{array}{l}p \text {-Value } \\
\text { (avs.c) }\end{array}$ & $\begin{array}{c}J A K 2 V 617 F \\
\text { Mutation } \\
n=29 \\
\left(\mathrm{a}^{1}\right)\end{array}$ & $\begin{array}{c}\text { CALR } \\
\text { Mutation } \\
n=3 \\
\left(\mathrm{~b}^{1}\right)\end{array}$ & $\begin{array}{c}\text { Triple } \\
\text { Negative } \\
n=9 \\
\left(c^{1}\right)\end{array}$ & $\begin{array}{c}p \text {-Value } \\
\left(a^{1} \text { vs. } b^{1}\right)\end{array}$ & $\begin{array}{c}p \text {-Value } \\
\left(b^{1} \text { vs. } c^{1}\right)\end{array}$ & $\begin{array}{c}p \text {-Value } \\
\left(a^{1} \text { vs. } c^{1}\right)\end{array}$ \\
\hline${ }^{2}$ Age, years & $60(43-79)$ & $61(38-75)$ & $55(32-73)$ & 0.779 & 0.457 & 0.177 & $51(33-86)$ & $69(41-81)$ & $52(23-75)$ & 0.348 & 0.165 & 0.336 \\
\hline${ }^{2}$ Hemoglobin, g/dL & $\begin{array}{c}11.25 \\
(6.5-20.20)\end{array}$ & $11.25(7.1-12.4)$ & $11.55(7.4-16.5)$ & 0.695 & 0.264 & 0.537 & $14.4(9-18)$ & $\begin{array}{c}13.2 \\
(9.1-14.4)\end{array}$ & $\begin{array}{c}11.8 \\
(9.90-14.30)\end{array}$ & 0.184 & 0.782 & 0.004 \\
\hline${ }^{2}$ Hematocrit, \% & $36.1(18.8-60)$ & $36.05(33-77.0)$ & $36.55(23.846 .5)$ & 0.433 & 0.934 & 0.795 & $44.4(18-54.6)$ & $\begin{array}{c}39.3 \\
(27.6-42.8)\end{array}$ & $\begin{array}{c}39.8 \\
(30.1-43.5)\end{array}$ & 0.065 & 0.782 & 0.003 \\
\hline${ }^{2}$ Platelets, $n \times 10^{9} / \mathrm{L}$ & $\begin{array}{c}639.5 \\
(84-2035)\end{array}$ & $\begin{array}{c}723.5 \\
(208-1532)\end{array}$ & $254(33-541)$ & 0.737 & 0.048 & 0.002 & $\begin{array}{c}851 \\
(305-1597)\end{array}$ & $\begin{array}{c}1051 \\
(749-1129)\end{array}$ & $\begin{array}{c}1014 \\
(472-1454)\end{array}$ & 0.539 & 1.0 & 0.420 \\
\hline${ }^{2}$ Monocyte $\times 10^{9} / \mathrm{L}$ & $\begin{array}{c}0.98 \\
(0.29-3.99)\end{array}$ & $1.39(0.72-8.33)$ & $0.78(0.28-1.22)$ & 0.126 & 0.012 & 0.196 & $\begin{array}{c}0.58 \\
(0.3-1.44)\end{array}$ & $\begin{array}{c}0.42 \\
(0.32-0.61)\end{array}$ & $\begin{array}{c}0.68 \\
(0.15-0.92)\end{array}$ & 0.244 & 0.302 & 0.834 \\
\hline $\begin{array}{l}{ }^{2} \mathrm{LDH}, \mathrm{U} / \mathrm{L} \\
\mathrm{ULN}>400\end{array}$ & $\begin{array}{c}852 \\
(397-4145)\end{array}$ & $2071(614-5842)$ & $530(262-1355)$ & 0.056 & 0.009 & 0.060 & $\begin{array}{c}534.5 \\
(351-1459)\end{array}$ & $616(450-662)$ & $\begin{array}{c}449.0 \\
(354-1880)\end{array}$ & 0.546 & 0.424 & 0.809 \\
\hline${ }^{1}$ Splenomegaly * & $17(77)$ & $4(66.7)$ & $5(35.7)$ & 0.622 & 0.336 & 0.013 & $10(34.5)$ & $2(66.7)$ & $3(33.3)$ & 0.54 & 0.523 & 1.0 \\
\hline${ }^{1}$ Liver * & $13(59.1)$ & $2(33.3)$ & $5(35.7)$ & 0.372 & 1.0 & 0.171 & $3(10.3)$ & $1(33.3)$ & $3(33.3)$ & 0.34 & 1.0 & 0.131 \\
\hline${ }^{1}$ Thrombotic events * & $7(31.8)$ & 0 & $11(78.6)$ & 0.288 & 0.001 & 0.006 & $12(41.4)$ & $1(33.3)$ & $3(33.3)$ & 1.0 & - & - \\
\hline
\end{tabular}

(i) * All of these variables are presented with $n$ (\%); (ii) all the results were within $95 \%$ CI. ${ }^{1}$ Fisher's exact test; ${ }^{2}$ Mann-Whitney U-test; $p<0.05$ is statistically significant. 


\section{Discussion}

The JAK2V617F mutation plays a decisive role as a screening tool for the diagnosis of MPN, particularly for PV. To date, additional mutations such as CALR and MPL mutations are also useful to confirm (Philadelphia) Ph-MPN. Despite the stringent diagnostic criteria outlined by the WHO edition, the diagnosis of JAK2V617F-negative in PV, ET, and PMF is still challenging to clinicians because $27.7 \%$ of our MPN patients were triple-negative. Thus, the morphological examination of bone marrow remains the fundamental investigation to diagnose Ph-MPN, especially triple-negative MPN.

There is a slight gender bias in MPNs, with a predominance of males over females, in agreement with other literature. However, there is some inconsistency between the subtypes [17]. In this study, the mean age for JAK2V617F-mutated patients is older compared to those with the wild type. This probably reflects that the mutation was acquired throughout the aging process.

Hitherto, there have been limited data on JAK2V617F, CALR, and MPL mutations and their correlation with clinical and hematological parameters in the region. The subtypes of MPN of $47.8 \%, 25.8 \%$, and $26.4 \%$ for PV, ET, and PMF, respectively, detected in this study, were similar to prospective cohort studies among Asian and German populations [18,19].

In our study, JAK2V617F was the most prevalent mutation in MPN, accounting for $73.6 \%$ of our population. The detection rates of the JAK2V617F mutation in PV, ET, and PMF patients were $86.8 \%, 70.7 \%$, and $52.3 \%$, respectively. These findings were similar to those in Chinese and Sudanese populations, where the JAK2V617F mutation was 85-91\% in PV, 54\% in ET, and 65.8\% in PMF [20,21].

In this study, $5.66 \%$ of $C A L R$ mutations were detected among MPN patients who were diagnosed as PMF and ET without JAK2V617F and MPL mutations. None of our PV patients had CALR mutations. These findings were consistent with a Slovenian cohort study by Belcic et al., which showed that about $4.4 \%$ of their patients had CALR mutations [11]. In contrast to Korean, Chinese, and American patients, PMF and ET patients showed higher percentages of CALR mutations, estimated to range from $12.6 \%$ to $89 \%$, compared to our study range of $7.3-14.3 \%[20,22,23]$. This was possibly due to differences in (1) the analytical sensitivities of the methods used and (2) the geographical distribution of the study population. Similar to other studies, the predominant type of CALR was Type 1 (77.78\%) [22].

Interestingly, our results showed that none of our MPN patients had MPL W515L/K mutations. Lieu and Eldeweny et al. also reported that MPL W515L/K could not be found in 88 Taiwanese and 60 Egyptian patients with MPN [24,25]. Only 1-4\% of MPL mutations were reported in two studies conducted among Korean and Chinese populations [20], [22]. Likewise, the MPL mutation was detected in $4-6 \%$ of ET and PMF in Iranian and Turkish populations $[6,26]$. This small discrepancy may be due to differences in ethnicity. None of the double mutations for MPL and CALR have been acknowledged in our study, similar to the finding of Lang et al. [27].

The frequency of our triple-negative mutations was $27.7 \%$, which was similar to a Korean study (20\%) [22]. Otherwise, the frequencies of the triple-negative mutations were found to be lower $(10-15 \%)$ in Indian and Slovenia studies [11,28]. Other types of clonal mutations, such as ASLX1, EZH2, TET2, IDH1/IDH2, SRSF2, and SF3B1 genes, may be demonstrated in PMF patients [29]. Apart from that, the method for mutational detection in this study was an allele-specific test that was designed to assess only hotspot mutations [30]. On the other hand, ET patients may have small mutant allele fractions that are lower than the limit of the detection method, leading to false-negative results.

There was a lack of clinically relevant patients with splenomegaly. However, a more extensive cohort study among the Busan Korean population found that larger spleen volumes at presentation may predict poor prognosis and a risk to fibrotic transformation or leukemia transformation [31,32]; $36.8 \%$ of our PV patients had splenomegaly in line with previous literature, and $6.57 \%$ had transformed to myelofibrosis. 
The hematological parameters of PV patients in this study showed typical panmyelosis, as described in the WHO revised edition of 2016. The JAK2 mutation is a key player in autonomous red cell production and the stimulation of myeloid and megakaryocytic lineages. The substitution of valine to phenylalanine at the 617 position of the JAK2 gene leads to the continuous activation of cytokine receptors, i.e., erythropoietin, thrombopoietin, and granulocyte colony-stimulating factors, resulting in an amplified production of RBCs, leukocytes, and platelets [33].

Our ET and PMF patients, similar to a previous study of Spanish, Korean, and Mexican patients, demonstrated that those with CALR mutations had higher platelet counts than those with other mutations $[22,34,35]$.

The majority of PMF JAK2V617F-mutated patients in this study showed monocytosis. It is noted that monocytosis is associated with short survival and rapid disease progression [36-38]. However, the relationship between monocytosis and survival analysis in this study is unknown due to the lack of survival data.

In this study, PMF patients had very high serum LDH compared to JAK2V617Fnegative ET and PV patients. Serum LDH was currently reconstituted as part of minor diagnostic criteria for PMF $[13,38]$. Nonetheless, increased LDH is not specific to PMF, as it can also be seen in ET and PV [39]. The utility of serum LDH is not only limited to the diagnosis of MPN, but it can also be used as one of the prognostic markers. A study by Shah and Busque et al. proposed that marked elevation of serum LDH $\geq 1000 \mathrm{U} / \mathrm{L}$ may predict a shorter survival outcome. The basis of this proposal lies in the fact that LDH is known to be associated with rapid cell turnover and ineffective hematopoiesis and hemolytic processes occurring in the spleen [40,41].

MPN is known to have an increased risk of thrombosis. We observed that thrombotic events at initial diagnosis in $40.9 \%$ of our MPN patients were higher than the global incidence of 20\% [42]. The risk of thrombosis was higher among ET, followed by PV, in JAK2V617F-positive patients. The pathophysiology behind the thrombotic risk in PV is due to increased blood viscosity, secondary to high hematocrit levels, and the migration of platelets to the vessel wall and subsequent platelet activation [43]. As in ET, it may be due to increased myeloid production, activation of leukocytes, and endothelial dysfunction [44]. It is postulated that MPN clonal cells induce the release of inflammatory cytokines, which results in procoagulant states. This finding is supported by blood-clotting markers, i.e., thrombin antithrombin complex, thrombomodulin, von Willebrand factor/factor V111, and prothrombin fragment $1+2$ [45]. The majority of our MPN patients had thrombotic events that were commonly due to arterial thrombosis compared to venous thrombosis; this is consistent with most studies [42].

Interestingly, this study showed that PV has a higher risk of evolving into post PV myelofibrosis compared to ET at the median of 54 (24-132) months. Only one PMF patient with the CALR mutation transformed to acute myeloid leukemia after 20 years of follow-up. This finding can be due to de novo or secondary to underlying disease (MPN); further investigation on the mechanism of leukemogenesis is needed. More cases are required to confirm the progression of the disease. None of the ET patients had disease progression or leukemic transformation in this study. Therefore, distinguishing subtypes play a major role in risk stratification.

\section{Conclusions}

The practical purposes of the current study are summarized as follows. (1) Identifying these molecular genes is important in the diagnosis of Ph- MPN, especially since the presentation may overlap with the reactive causes and other myelodysplastic/myeloproliferative diseases. (2) CALR is the second-most frequently detected mutation in MPN; therefore, it is part of the diagnostic tools for MPN, especially in JAK2V617F-negative PMF and ET. (3) Bone marrow morphology remains the backbone of MPN diagnosis because up to $20 \%$ of triple negatives have an absence of MPN-definite molecular markers. 
Despite a small cohort, the results of this study should be heeded as this is the first report on the frequency of JAK2V617F, CALR, and MPL mutations in relation to the biological and clinical features of MPN among Malaysians.

Author Contributions: Conceptualization, R.H.Z., Z.Z. and R.H.; methodology, R.H.Z., M.F.J. and A.H.; software, M.A.I.; validation, Z.Z. and R.H.; formal analysis, R.H.Z., Z.Z. and R.H.; writingoriginal draft preparation, R.H.Z.; writing—-review and editing, R.H.Z., Z.Z., R.H., M.F.J., A.H. and M.A.I.; supervision, Z.Z., R.H., M.F.J., A.H. and M.A.I. All authors have read and agreed to the published version of the manuscript.

Funding: This research were funded by Universiti Sains Malaysia Postgraduate Publication Grant 1001/PPSP/8070011 and Research University Individual grant 1001/PPSK/8012213.

Institutional Review Board Statement: This study was approved by the Institutional Review Board of the Human Research Ethics Committee, Universiti Sains Malaysia Research Ethics Committee (JePeM code: USM/JEPeM 19100646), and carried out in accordance with the Declaration of Helsinki.

Informed Consent Statement: Not applicable.

Data Availability Statement: The data presented in this study are available on request from the corresponding author.

Acknowledgments: The authors would like to thank the Department of Haematology, School of Medical Sciences, Universiti Sains Malaysia, for providing the archived DNA samples and facilities used in this study.

Conflicts of Interest: The authors declare no conflict of interest. The funders had no role in the design of the study; in the collection, analyses, or interpretation of data; in the writing of the manuscript, or in the decision to publish the results.

\section{Appendix A}

Table A1. Accession numbers of DNA sequences.

\begin{tabular}{ccccc}
\hline Gene & $\begin{array}{c}\text { Chromosome } \\
\text { Location }\end{array}$ & Region (Base) & Size (bp) & $\begin{array}{c}\text { NCBI Reference } \\
\text { Sequence }\end{array}$ \\
\hline$J A K 2^{V 617 F}$ & $9 \mathrm{p} 24.1$ & 93497 to 93523 & 203 & NG_009904.1 \\
\hline CALR-TYPE 1 & $19 \mathrm{p} 13$ & 10114 to 10135 & 302 & NG_029662.1 \\
\hline CALR-TYPE 2 & $19 \mathrm{p} 13$ & 10204 to 10219 & 272 & NG_029662.1 \\
\hline$M P L-W 515 L$ & $1 \mathrm{p} 34$ & 16516 to 16535 & 124 & NG_007525.1 \\
\hline$M P L-W 515 K$ & $1 \mathrm{p} 34$ & 16535 to 16555 & 125 & NG_007525.1 \\
\hline
\end{tabular}

Table A2. Primers for JAK2 V617F, CALR, and MPL mutation screening.

\begin{tabular}{|c|c|c|}
\hline Primer Name & Mutant Sequences & PCR Product Size (bp) \\
\hline$J A K 2^{V 617 F}$ & $\begin{array}{l}\text { FC 5'- ATC TAT AGT CAT GCT GAA AGT AGG AGA } \\
\text { AAG-3' } \\
\text { FS 5'- AGC ATT TGG TTT TAA ATT ATG GAG TAT ATT-3' } \\
\text { R 5'-CTG AAT AGT CCT ACA GTG TTT TCA GTT TCA-3' }\end{array}$ & $\begin{array}{c}364 \text { bp only (Wild-type) } \\
203 \text { bp }\end{array}$ \\
\hline $\begin{array}{l}C A L R-T Y P E 1 \\
C A L R-T Y P E 2\end{array}$ & $\begin{array}{c}\text { Type 1: F1 (forward primer 1) } \\
\text { 5'-GCA GCA GAG AAA CAA ATG AAG G-3' } \\
\text { Type 2: F2 (forward primer 2) } \\
\text { 5'-GCA GAG GAC AAT TGT CGG A-3', } \\
\text { R (reverse primer) 5'-AGA GTG GAG GAG GGG AAC } \\
\text { AA-3' }\end{array}$ & $\begin{array}{l}357 \text { bp only (Wild type) } \\
302 \text { bp (Type 1) } \\
272 \text { bp (Type } 2)\end{array}$ \\
\hline $\begin{array}{l}M P L-W 515 L \\
M P L-W 515 K\end{array}$ & $\begin{array}{c}\text { GCC GAA GTC TGA CCC TTT TT } \\
\text { Forward (L): GGC CTG CTG CTG CTG AAG Tt } \\
\text { Reverse (K)TGT AGT GTG CAG GAA ACT GCtt } \\
\text { R: ACA GAG CGA ACC AAG AAT GCC TGT TTA CA }\end{array}$ & $\begin{array}{c}209 \text { bp only (Wild-type) } \\
124 \text { bp (L) } \\
125 \text { bp (K) }\end{array}$ \\
\hline
\end{tabular}

Refs. [46,47]. 
Table A3. PCR conditions for CALR and MPL.

\begin{tabular}{cccccc}
\hline & \multicolumn{2}{c}{ CALR } & \multicolumn{2}{c}{ MPL } \\
\hline \multicolumn{2}{c}{ Cycles } & Temperature $\left({ }^{\circ} \mathbf{C}\right)$ & Time & Temperature $\left({ }^{\circ} \mathbf{C}\right)$ & Time \\
\hline \multirow{2}{*}{ Initial denaturation } & 94 & $10 \mathrm{~min}$ & 95 & $10 \mathrm{~min}$ \\
\hline \multirow{3}{*}{ PCR $(\times 40$ cycles $)$} & Denaturing & 94 & $30 \mathrm{~s}$ & 95 & $30 \mathrm{~s}$ \\
\cline { 2 - 6 } & Annealing & 65 & $30 \mathrm{~s}$ & 54 & $30 \mathrm{~s}$ \\
\cline { 2 - 6 } & Extension & 72 & $30 \mathrm{~s}$ & 72 & $30 \mathrm{~s}$ \\
\hline Final extension & 72 & $7 \mathrm{~min}$ & 72 & $10 \mathrm{~min}$ \\
\hline \multicolumn{2}{c}{ Hold } & 4 & $\infty$ & 4 & $\infty$ \\
\hline
\end{tabular}

Table A4. Constituents for PCR and its volume.

\begin{tabular}{|c|c|c|c|c|}
\hline \multirow[b]{2}{*}{ Constituents } & \multicolumn{2}{|c|}{ CALR } & \multicolumn{2}{|c|}{ MPL } \\
\hline & Concentration & Volume $(\mu \mathrm{L})$ & Concentration & Volume $(\mu \mathrm{L})$ \\
\hline $\begin{array}{c}\text { 10× Gene Amp PCR } \\
\text { Buffer II }\end{array}$ & $1 \times$ & 2.0 & $1 \times$ & 2.0 \\
\hline $\begin{array}{c}25 \mathrm{mM} \text { Gene Amp } \\
\mathrm{MgCl}_{2}\end{array}$ & $2.5 \mathrm{mM}$ & 2.0 & $2.5 \mathrm{mM}$ & 2.0 \\
\hline $\begin{array}{l}10 \mu \mathrm{M} \text { Gene Amp } \\
\text { Dntp blend }\end{array}$ & $0.1 \mathrm{mM}$ & 0.2 & $0.1 \mathrm{mM}$ & 0.32 \\
\hline $5 \mu \mathrm{M}$ Primer FC & $0.2 \mu \mathrm{M}$ & 0.5 & & \\
\hline $5 \mu \mathrm{M}$ Primer FS & $0.2 \mu \mathrm{M}$ & 0.5 & & \\
\hline $5 \mu \mathrm{M}$ Primer $\mathrm{R}$ & $0.2 \mu \mathrm{M}$ & 1.0 & & \\
\hline 5 U Ampli Taq Gold & $0.025 \mathrm{u}$ & 0.1 & $0.025 \mathrm{u}$ & 0.19 \\
\hline PCR Water & & 8.7 & & 4.99 \\
\hline DNA (100-200 ng) & $25-50 \mathrm{ng} / \mu \mathrm{L}$ & 5 & $25-50 \mathrm{ng} / \mu \mathrm{L}$ & 5 \\
\hline
\end{tabular}

\section{References}

1. Mêd, A.J.; Mullally, A. Myeloproliferative neoplasm stem cells. Blood 2017, 129, 1607-1616. [CrossRef] [PubMed]

2. Spivak, J.L. Myeloproliferative Neoplasms. N. Engl. J. Med. 2017, 376, 168-2181. [CrossRef]

3. Grinfeld, J.; Nangalia, J.; Baxter, E.J.; Wedge, D.C.; Angelopoulos, N.; Cantrill, R.; Godfrey, A.L.; Papaemmanuil, E.; Gundem, G.; MacLean, C.; et al. Classification and Personalized Prognosis in Myeloproliferative Neoplasms. N. Engl. J. Med. 2018, 379, 1416-1430. [CrossRef] [PubMed]

4. Xie, J.; Hen, X.; Gao, F.; Hou, R.; Tian, T.; Zhang, Y.; Fan, L.; Hu, J.; Zhu, G.; Yang, W.; et al. Two activating mutations of MPL in triple-negative myeloproliferative neoplasms. Cancer Med. 2019, 8, 5254-5263. [CrossRef] [PubMed]

5. Pizzi, M. Crossing the borders: An integrated approach to myeloproliferative neoplasms and mastocytoses. Cancers 2021, 13, 1492. [CrossRef] [PubMed]

6. Shams, S.F.; Ayatollahi, H.; Sadeghian, M.H.; Afzalaghaee, M.; Shakeri, S.; Yazdandoust, E.; Sheikhi, M.; Amini, N.; Bakhshi, S.; Bahrami, A. Prevalence of MPL (W515K/L) Mutations in Patients with Negative-JAK2 (V617F) Myeloproliferative Neoplasm in North-East of Iran. Iran. J. Pathol. 2018, 13, 397-402.

7. Zhang, S.P.; Li, H.; Lai, R.S. Detection of JAK2 V617F mutation increases the diagnosis of myeloproliferative neoplasms. Oncol. Lett. 2015, 9, 735-738. [CrossRef] [PubMed]

8. Azevedo, A.P.; Silva, S.N.; Reichert, A.; Lima, F.; Júnior, E.; Rueff, J. Prevalence of the janus kinase 2 V617F mutation in philadelphia-negative myeloproliferative neoplasms in a portuguese population. Biomed. Rep. 2017, 7, 370-376. [CrossRef] [PubMed]

9. Nangalia, J.; Green, A.R. Myeloproliferative neoplasms: From origins to outcomes. Blood 2017, 130, 2475-2483. [CrossRef]

10. Machado-Neto, J.A.; Campos, P.d.; Trainaen, F. CALR (calreticulin). Atlas Genet. Cytogenet. Oncol. Haematol. 2018. [CrossRef]

11. Mikic, T.B.; Pajic, T.; Sever, M. CALR mutations in a cohort of JAK2 V617F negative patients with suspected myeloproliferative neoplasms. Sci. Rep. 2019, 9, 1-9. [CrossRef]

12. Grabek, J.; Straube, J.; Bywater, M.; Lane, S.W. MPN: The Molecular Drivers of Disease Initiation, Progression and Transformation and their Effect on Treatment. Cells 2020, 9, 1901. [CrossRef] 
13. Arber, D.A.; Orazi, A.; Hasserjian, R.; Thiele, J.; Borowitz, M.J.; Le Beau, M.M.; Bloomfield, C.D.; Cazzola, M.; Vardiman, J.W. The 2016 revision to the World Health Organization classification of myeloid neoplasms and acute leukemia. Blood 2016, 127, 2391-2405. [CrossRef] [PubMed]

14. Swerdlow, S.H.; Campo, E.; Harris, N.L.; Jaffe, E.S.; Pileri, S.A.; Stein, H.; Thiele, J. World Health Organization Classification of Tumours of Haematopoietic and Lymphoid Tissues Revised, 4th ed.; International Agency for Research on Cancer (IARC): Lyon, France, 2017.

15. QIAGEN Group. QIAsymphony DNA Handbook; Forest Stewardship Council (FSC): Foster City, CA, USA, 2010.

16. Zakaria, N.A.; Rosle, N.A.; Asmaa, M.J.S.; Aziee, S.; Haiyuni, M.Y.; Samat, N.A.; Husin, A.; Hassan, R.; Ramli, M.; Yusoff, S.M.; et al. Conformation sensitive gel electrophoresis for the detection of calreticulin mutations in BCR-ABL1-negative myeloproliferative neoplasms. Int. J. Lab. Hematol. 2021. [CrossRef]

17. Heppner, J.; Nguyen, L.T.; Guo, M.; Naugler, C.F.; Rashid-Kolvear, F. Incidence of myeloproliferative neoplasms in Calgary, Alberta, Canada. BMC Res. Notes 2019, 12, 286. [CrossRef] [PubMed]

18. Kaifie, A.; Kirschner, M.; Wolf, D.; Maintz, C.; Hänel, M.; Gattermann, N.; Gökkurt, E.; Platzbecker, U.; Hollburg, W.; Göthert, J.R.; et al. Bleeding, thrombosis, and anticoagulation in myeloproliferative neoplasms (MPN): Analysis from the German SAL-MPN-registry. J. Hematol. Oncol. 2016, 9, 18. [CrossRef]

19. Yassin, M.A.; Taher, A.; Mathews, V.; Hou, H.-A.; Shamsi, T.; Tuglular, T.; Xiao, Z.; Kim, S.-J.; Wu, D.; Li, J.; et al. Myeloproliferative Neoplasms in Asia, Including Middle East, Turkey, and Algeria: Epidemiological Indices and Treatment Practice Patterns from the Multinational, Multicenter, Observational MERGE Registry. Blood 2018, 132, 5461. [CrossRef]

20. Lin, Y.; Liu, E.; Sun, Q.; Ma, J.; Li, Q.; Cao, Z.; Wang, J.; Jia, Y.; Zhang, H.; Song, Z.; et al. The prevalence of JAK2, MPL, and CALR mutations in Chinese patients with BCR-ABL1-Negative Myeloproliferative Neoplasms. Am. J. Clin. Pathol. 2015, 144, 165-171. [CrossRef]

21. Ibrahim, I.K.; Hassan, R.; Ali, E.W.; Omer, A. Polycythaemia vera among Sudanese patients with special emphasis on JAK2 mutations. Asian Pac. J. Cancer Prev. 2019, 20, 41-44. [CrossRef]

22. Kim, B.H.; Cho, Y.U.; Bae, M.H.; Jang, S.; Seo, E.J.; Chi, H.S.; Choi, Y.; Kim, D.Y.; Lee, J.H.; Lee, J.H.; et al. JAK2 V617F, MPL, and CALR mutations in Korean patients with essential thrombocythemia and primary myelofibrosis. J. Korean Med. Sci. 2015, 30, 882-888. [CrossRef]

23. Loghavi, S.; Bueso-Ramos, C.E.; Kanagal-Shamanna, R.; Ok, C.Y.; Salim, A.A.; Routbort, M.J.; Mehrotra, M.; Verstovsek, S.; Medeiros, L.J.; Luthra, R.; et al. Myeloproliferative neoplasms with calreticulin mutations exhibit distinctive morphologic features. Am. J. Clin. Pathol. 2016, 145, 418-427. [CrossRef]

24. Lieu, C.H.; Shen, Y.J.; Lai, W.C.; Tsai, W.H.; Hsu, H.C. Prevalence of MPL W515L/K Mutations in Taiwanese Patients With Philadelphia-negative Chronic Myeloproliferative Neoplasms. J. Chin. Med. Assoc. 2010, 73, 530-532. [CrossRef]

25. Eldeweny, S.; Ibrahim, H.; Elsayed, G.; Samra, M. MPL W515 L/K mutations in myeloproliferative neoplasms. Egypt. J. Med. Hum. Genet. 2019, 20, 31. [CrossRef]

26. Akpinar, T.S.; Hançer, V.S.; Nalçaci, M.; Diz-Küçükkaya, R. Kronik miyeloproliferatif neoplazmlarda MPL W515L/K mutasyonlari. Turk. J. Hematol. 2013, 30, 8-12. [CrossRef] [PubMed]

27. Lang, T.; Nie, Y.; Wang, Z.; Huang, Q.; An, L.; Wang, Y.; Wufuer, G.; Maimaiti, A.; Fu, L.; Li, Y.; et al. Correlation analysis between JAK2, MPL, and CALR mutations in patients with myeloproliferative neoplasms of Chinese Uygur and Han nationality and their clinical characteristics. J. Int. Med. Res. 2018, 46, 4650-4659. [CrossRef]

28. Rabade, N.; Subramanian, P.G.; Kodgule, R.; Raval, G.; Joshi, S.; Chaudhary, S.; Mascarenhas, R.; Tembhare, P.; Gujral, S.; Patkar, N. Molecular genetics of BCR-ABL1 negative myeloproliferative neoplasms in India. Indian J. Pathol. Microbiol. 2018, 61, 209-213. [CrossRef]

29. Passamonti, F.; Maffioli, M. Update from the latest WHO classification of MPNs: A user's manual. Hematology 2016, 2016, 534-542. [CrossRef] [PubMed]

30. Xia, D.; Hasserjian, R.P. Molecular testing for JAK 2, MPL, and CALR in myeloproliferative neoplasms. Am. J. Hematol. 2016, 91, 1277-1280. [CrossRef]

31. Song, M.-K.; Chung, J.-S.; Lim, S.-N.; Lee, G.-n.; Lee, S.-M.; Lee, N.-K.; Choi, J.-C.; Oh, S.-Y. Usefulness of spleen volume measured by computed tomography for predicting clinical outcome in primary myelofibrosis. Int. J. Hematol. 2016, 104, 476-484. [CrossRef]

32. Iurlo, A.; Cattaneo, D.; Bucelli, C.; Baldini, L. New perspectives on polycythemia vera: From diagnosis to therapy. Int. J. Mol. Sci. 2020, 21, 5805. [CrossRef] [PubMed]

33. Ashorobi, D.; Gohari, P. Essential Thrombocytosis; StatPearls Publishing: New York, NY, USA, 2020.

34. Alvarez-Larran, A.; Martínez, D.; Arenillas, L.; Rubio, A.; Arellano-Rodrigo, E.; Hernández Boluda, J.C.; Papaleo, N.; Caballero, G.; Martínez, C.; Ferrer-Marín, F.; et al. Essential thrombocythaemia with mutation in MPL: Clinicopathological correlation and comparison with JAK 2V617F-mutated and CALR- mutated genotypes. J. Clin. Pathol. 2018, 71, 975-980. [CrossRef]

35. Labastida-Mercado, N.; Galindo-Becerra, S.; Garcés-Eisele, J.; Colunga-Pedraza, P.; Guzman-Olvera, V.; Reyes-Nuñez, V.; RuizDelgado, G.J.; Ruiz-Argüelles, G.J. The mutation profile of JAK2, MPL and CALR in Mexican patients with Philadelphia chromosome-negative myeloproliferative neoplasms. Hematol. Oncol. Stem Cell Ther. 2015, 8, 16-21. [CrossRef]

36. Boiocchi, L.; Espinal-Witter, R.; Geyer, J.T.; Steinhilber, J.; Bonzheim, I.; Knowles, D.M.; Fend, F.; Orazi, A. Development of monocytosis in patients with primary myelofibrosis indicates an accelerated phase of the disease. Mod. Pathol. 2013, 26, $204-212$. [CrossRef] 
37. Shah, A.; Mudireddy, M.; Lasho, T.L.; Barraco, D.; Hanson, C.A.; Ketterling, R.P.; Gangat, N.; Elliott, M.; Pardanani, A.; Tefferi, A. Monocytosis Is a Powerful and Independent Predictor of Shortened Overall and Leukemia-Free Survival in Primary Myelofibrosis. Blood 2016, 128, 4249. [CrossRef]

38. Barbui, T.; Thiele, J.; Gisslinger, H.; Kvasnicka, H.M.; Vannucchi, A.M.; Guglielmelli, P.; Orazi, A.; Tefferi, A. The 2016 WHO classification and diagnostic criteria for myeloproliferative neoplasms: Document summary and in-depth discussion. Blood Cancer J. 2018, 8, 15. [CrossRef] [PubMed]

39. Beer, P.A.; Campbell, P.J.; Green, A.R. Comparison of different criteria for the diagnosis of primary myelofibrosis reveals limited clinical utility for measurement of serum lactate dehydrogenase. Haematologica 2010, 95, 1960-1963. [CrossRef] [PubMed]

40. Busque, L.; Porwit, A.; Day, R.; Olney, H.J.; Leber, B.; Éthier, V.; Sirhan, S.; Foltz, L.; Prchal, J.; Kamel-Reid, S.; et al. Laboratory Investigation of Myeloproliferative Neoplasms (MPNs). Am. J. Clin. Pathol. 2016, 146, 408-422. [CrossRef]

41. Shah, S.; Mudireddy, M.; Hanson, C.A.; Ketterling, R.P.; Gangat, N.; Pardanani, A.; Tefferi, A. Marked elevation of serum lactate dehydrogenase in primary myelofibrosis: Clinical and prognostic correlates. Blood Cancer J. 2017, 7, 657. [CrossRef]

42. Rungjirajittranon, T.; Owattanapanich, W.; Ungprasert, P.; Siritanaratkul, N.; Ruchutrakool, T. A systematic review and metaanalysis of the prevalence of thrombosis and bleeding at diagnosis of Philadelphia-negative myeloproliferative neoplasms. BMC Cancer 2019, 19, 1-9. [CrossRef]

43. Aksit, M.; Bozkaya, G.; Uzuncan, N.; Bilgili, S.; Ozlu, C.; Aksit, M.Z. Relationship between JAK2-V617F mutation and hematologic parameters in Philadelphia-negative chronic myeloproliferative neoplasms. Turkish J. Biochem. 2020, 45, 899-905. [CrossRef]

44. Chia, Y.C.; Ramli, M.; Woon, P.Y.; Johan, M.F.; Hassan, R.; Islam, M.A. Molecular genetics of thrombotic myeloproliferative neoplasms: Implications in precision oncology. Genes Dis. 2021. [CrossRef]

45. Yap, Y.Y.; Law, K.B.; Sathar, J.; Lau, N.S.; Goh, A.S.; Chew, T.K.; Lim, S.M.; Menon, P.; Guan, Y.K.; Husin, A.B.; et al. The epidemiology and clinical characteristics of myeloproliferative neoplasms in Malaysia. Exp. Hematol. Oncol. $2018,7,31$. [CrossRef]

46. Chi, J.; Ch, P.; Mitsidou, A. A sensitive detection method for MPLW515L or MPLW515K mutation in myeloproliferative disorders. Euro. J. Exp. Biol. 2014, 4, 33-36.

47. Jeong, J.H.; Lee, H.T.; Seo, J.Y.; Seo, Y.H.; Kim, K.H.; Kim, M.J.; Lee, J.H.; Park, J.; Hong, J.S.; Park, P.W.; et al. Screening PCR versus sanger sequencing: Detection of CALR mutations in patients with thrombocytosis. Ann. Lab. Med. 2016, 36, 291-299. [CrossRef] [PubMed] 